\title{
Genome-wide analysis of the WRKY gene family and their positive responses to phytoplasma invasion in Chinese jujube
}

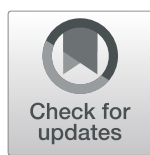

Chaoling Xue ${ }^{1,2 \dagger}$, Hongtai Li ${ }^{1,2 \dagger}$, Zhiguo Liư ${ }^{3}$, Lili Wang ${ }^{3}$, Yitong Zhao ${ }^{1}$, Ximeng Wei ${ }^{1}$, Hu Fang ${ }^{4}$, Mengjun Liu ${ }^{3 *}$ and Jin Zhao ${ }^{1,2^{*}}$ (D)

\begin{abstract}
Background: The WRKY gene family is one of the most important families in higher plants. As transcription factors, they actively respond to biotic and abiotic stress and are also involved in plant development. Chinese jujube (Ziziphus jujuba Mill.) is the largest type of dried fruit tree in China in terms of production, but its production is largely limited by phytoplasma infection, and the information about the role of WRKY genes under phytoplasma stress was still limited.

Results: We identified 54 ZjWRKYS in the jujube genome and classified them into three subgroups according to conserved WRKY domains and zinc-finger structure. 41 ZjWRKYs were distributed on 11 of 12 pseudo chromosomes in Chinese jujube. The majority of ZjWRKYs were highly expressed in the seven examined tissues, indicating that they play multiple roles in these vegetative and reproductive organs. Transcriptome data showed that most of the characterised ZjWRKYS were highly expressed at later stages of fruit development. RT-qPCR demonstrated that the expression of 23 ZjWRKYS changed following phytoplasma infection, suggesting that they are involved in signalling pathways that respond to phytoplasma stress. Then, STRING analysis and yeast two-hybrid screening proved that some ZjWRKY proteins were interacting with ZjMAPKK proteins, which were also involved in phytoplasma invasion. Moreover, their differential expressions were further confirmed in resistant and susceptible jujube varieties under phytoplasma stress. These results suggest that ZjWRKYs play significant roles in phytoplasma tolerance and should be crucial candidate genes for jujube-phytoplasma interaction.
\end{abstract}

Conclusions: 54 ZjWRKYs in Chinese jujube were identified and classified into three subgroups. 41 ZjWRKYs were unevenly distributed along the chromosomes. The majority of ZjWRKYY were highly expressed in various tissues. Most of the ZjWRKYS were positive responses to phytoplasma invasion, and that provided candidate genes for the future studies of jujube-phytoplasma interaction.

Keywords: WRKYs, Chinese jujube, Bioinformatics analysis, Gene expression, Phytoplasma invasion

\section{Background}

The WRKY transcription factors (TFs) bind to a specific promoter sequence in the target gene, known as a W-box, and can positively or negatively regulate target gene expression. The WRKY proteins have one or two DNA binding domains that are 60 amino acids long and contain

\footnotetext{
*Correspondence: zhaojinbd@126.com; Imj1234567@aliyun.com

${ }^{+}$Chaoling Xue and Hongtai Li contributed equally to the work.

${ }^{1}$ College of Life Science, Hebei Agricultural University, Baoding, China

${ }^{3}$ Research Center of Chinese Jujube, Hebei Agricultural University, Baoding,

China

Full list of author information is available at the end of the article
}

the conserved heptapeptide WRKYGQK followed by a zinc-finger motif $\mathrm{C}_{2} \mathrm{H}_{2}\left(\mathrm{CX}_{4-5} \mathrm{CX}_{22-23} \mathrm{HXH}\right)$ or $\mathrm{C}_{2} \mathrm{HC}$ $\left(\mathrm{CX}_{7} \mathrm{CX}_{23-24} \mathrm{HXC}\right)$ [1]. The WRKY family contains important transcription factors that have multiple functions in processes such as embryogenesis [2], trichome and seed development [3], leaf senescence [4], flowering [5], fruit and pollen development [6], biomass accumulation [7], secondary metabolite biosynthesis [8] and hormone signalling [9]. WRKY transcription factors are also crucial regulatory components of plant responses to pathogen infection. In Arabidopsis, several WRKY genes have been

(c) The Author(s). 2019 Open Access This article is distributed under the terms of the Creative Commons Attribution 4.0 International License (http://creativecommons.org/licenses/by/4.0/), which permits unrestricted use, distribution, and reproduction in any medium, provided you give appropriate credit to the original author(s) and the source, provide a link to the Creative Commons license, and indicate if changes were made. The Creative Commons Public Domain Dedication waiver (http://creativecommons.org/publicdomain/zero/1.0/) applies to the data made available in this article, unless otherwise stated. 
experimentally characterised and associated with responses to fungal or bacterial pathogens [10-12]. AtWRKY70 is required for $\mathrm{R}$ gene-mediated pathogen resistance, determining the balance between the SA- and JA-dependent defence systems $[13,14]$. Many WRKY genes also act in defence signalling; for example, AtWRKY38 and AtWRKY62 act as negative regulators of basal resistance towards bacterial pathogens [15]. In rice, overexpression of OsWRKY30 enhanced resistance to the rice sheath blight fungus Rhizoctonia solani and the blast fungus Magnaporthe grisea [16, 17]. Owing to their important roles, the WRKY family has been widely studied in many plant species, such as Arabidopsis, rice, grape, apple, pear, and peach [18-22]. However, the information of this gene family in Chinese jujube and their roles under phytoplasma stress was still limited.

Chinese jujube is the largest type of dried fruit tree in China in terms of production [23] and the most important species of family Rhamnaceae. It is cultivated mainly for its fruits, which can be eaten fresh or dried or as raw materials for making Chinese herbal medicine. However, jujube production is threatened by several devastating diseases, such as jujube witches' broom disease (JWB). The genome of Chinese jujube was recently published $[24,25]$, paving the way for further investigations. Our transcriptome data indicated that some WRKY genes respond to JWB phytoplasma infection. Since the WRKY family plays a crucial role in biotic stress response, identifying WRKY genes in Chinese jujube and determining their possible functions in response to phytoplasma stress have important significance.

Here, we report on the genome-wide analysis of the WRKY family in Chinese jujube. A non-redundant set of WRKY genes was identified in this species. Subsequently, chromosomal location was determined, phylogenetic and motif analyses were also performed as a base for further comparative genomics studies. Moreover, expression patterns of $Z j W R K Y \mathrm{~s}$ in various tissues and under phytoplasma stress were also investigated. The interacting proteins of ZjWRKYs were also screened. The ZjWRKYs involved in phytoplasma invasion were considered good candidates for subsequent studies of the jujube-phytoplasma interaction.

\section{Results}

\section{Identification of ZjWRKYs in Chinese jujube}

A total of 54 non-redundant putative WRKY coding sequences (Table 1) were identified in the jujube genome sequence. The sequences were named from $Z j W R K Y 1$ to $Z j W R K Y 54$ according to their gene structure and motifs. The ORF length for $Z j W R K Y$ genes ranged from $522 \mathrm{bp}$ (ZjWRKY26) to 2205 bp (ZjWRKY8), and they encoded proteins ranging from 173 to 734 amino acids (aa) in length, with predicted pIs ranging from 4.65 ( $Z j W R K Y 32)$ to 9.09 (ZjWRKY1) (Table 1).
Previous genome evolution studies showed that Chinese jujube is closely related to species of the family Rosaceae $[24,26]$, so the WRKY genes of three Rosaceae species (apple, pear and peach) and Arabidopsis were compared with that of Chinese jujube (Additional file 1). Compared with Arabidopsis, apple and pear [18, 19, 21], there are fewer WRKY genes in jujube, but the number was similar to that of peach [22]. The smaller number of WRKY genes in Chinese jujube and peach may be due to the occurrence of only one genome duplication event during the evolution of the two species [24, 27]. Based on the above comparison, it was suggested that most of the expected WRKY genes in jujube were identified.

\section{Conserved motifs and phylogenetic tree construction of ZjWRKYs}

The phylogenetic tree of the ZjWRKY proteins was constructed by aligning multiple domain sequences (Fig. 1). The ZjWRKY proteins were classified into three groups (Group I, II and III) (Table 1) according to their WRKY and zinc-finger motifs. The domain sequences in the ZjWRKY gene family were highly conserved. There were 8 motifs among ZjWRKYs and proteins in the same group had similar numbers and types of motifs (Fig. 2, Additional file 2). The WRKY domain (WRKYGQK, Motif 1) was highly conserved among the 54 proteins (Additional file 2) and only two of them contained variations. The group II proteins ZjWRKY25 and ZjWRKY26 showed a WRKY motif with one amino acid modifications (WRKYGKK) (Table 1, Fig. 2). Motif 2 was also highly conserved except in the two Group III proteins ZjWRKY52 and ZjWRKY53. Motif 5 and Motif 8 were specific to groups I and III respectively.

Group I had 8 proteins (Table 1), that contained two WRKY motifs, and two $\mathrm{C}_{2} \mathrm{H}_{2}$ zinc-finger motifs. Group II was the biggest group and included 34 proteins that contained a WRKY motif and a $\mathrm{C}_{2} \mathrm{H}_{2}$ zinc-finger motif. According to the phylogenetic analysis, the 34 genes could be further divided into five subgroups (IIa to e) that included 3, 10, 11, 3 and 7 genes, respectively (Table 1). The members of subgroups IIa, IIb, IId and IIe had a $\mathrm{CX}_{5} \mathrm{CX}_{23} \mathrm{HX}_{1} \mathrm{H}$ zinc-finger motif, while that of subgroup IIc had a $\mathrm{CX}_{4} \mathrm{CX}_{23} \mathrm{HX}_{1} \mathrm{H}$ structure (Table 1). Group III contained 12 proteins, and they had one WRKY motif and a $\mathrm{C}_{2} \mathrm{HC}$ zinc-finger motif $\left(\mathrm{CX}_{7} \mathrm{CX}_{23} \mathrm{HX}_{1} \mathrm{C}\right.$, Table 1$)$.

The chromosomal location and gene structure of ZjWRKYs Of the 54ZjWRKY genes, 41 were mapped to 11 of 12 pseudo chromosomes in the jujube genome (Fig. 3), and 13 genes were located on 12 scaffolds (Table 1, Additional file 3). $Z j W R K Y s$ were not evenly distributed across the 11 pseudo chromosomes (Fig. 3). Ten ZjWRKYs (18.5\%) were located on Chr. 11, whereas only one ZjWRKY gene was on Chr. 5 and 8 each. No 
Table 1 The information of WRKY gene family in Chinese jujube

\begin{tabular}{|c|c|c|c|c|c|c|c|c|c|c|}
\hline Gene Name & NCBI Reference & ORF (bp) & Size (aa) & $\mathrm{MW}(\mathrm{D})$ & $\mathrm{PI}$ & Conserved motif & Domain pattern & Zinc finger & Group & Exon number \\
\hline ZjWRKY1 & $\underline{X M \_016044069.1}$ & 1434 & 477 & 52053.75 & 9.09 & $2 \times[$ WRKYGQK] & $\mathrm{C}-\mathrm{X}_{4}-\mathrm{C}-\mathrm{X}_{22-23}-\mathrm{HXH}$ & $\mathrm{C}_{2} \mathrm{H}_{2}$ & I & 5 \\
\hline ZjWRKYZ & $\underline{X M \_016042179.1}$ & 1629 & 542 & 60186.57 & 7.09 & $2 \times[$ WRKYGQK] & $\mathrm{C}-\mathrm{X}_{4}-\mathrm{C}-\mathrm{X}_{22-23}-\mathrm{HXH}$ & $\mathrm{C}_{2} \mathrm{H}_{2}$ & । & 5 \\
\hline ZjWRKYY & $\underline{X M \_016047139.1}$ & 1904 & 583 & 63795.60 & 6 & $2 \times[\mathrm{WRKYGQK}]$ & $\mathrm{C}-\mathrm{X}_{4}-\mathrm{C}-\mathrm{X}_{22-23}-\mathrm{HXH}$ & $\mathrm{C}_{2} \mathrm{H}_{2}$ & I & 6 \\
\hline ZjWRKY4 & $\underline{\text { XM_016025559.1 }}$ & 1506 & 501 & 55188.92 & 6.52 & $2 \times[$ WRKYGQK] & $\mathrm{C}-\mathrm{X}_{4}-\mathrm{C}-\mathrm{X}_{22-23}-\mathrm{HXH}$ & $\mathrm{C}_{2} \mathrm{H}_{2}$ & । & 4 \\
\hline ZjWRKY5 & $\underline{X M \_016037165.1}$ & 1566 & 521 & 57263.14 & 5.12 & $2 \times[$ WRKYGQK] & $\mathrm{C}-\mathrm{X}_{4}-\mathrm{C}-\mathrm{X}_{22-23}-\mathrm{HXH}$ & $\mathrm{C}_{2} \mathrm{H}_{2}$ & I & 5 \\
\hline ZjWRKYG & $\underline{\text { XM_016019228.1 }}$ & 1077 & 358 & 39860.32 & 8.82 & $2 \times[$ WRKYGQK] & $\mathrm{C}-\mathrm{X}_{4}-\mathrm{C}-\mathrm{X}_{22-23}-\mathrm{HXH}$ & $\mathrm{C}_{2} \mathrm{H}_{2}$ & । & 4 \\
\hline ZjWRKYY & $\underline{X M \_016024358.1}$ & 1629 & 542 & 59088.72 & 8.91 & $2 \times[$ WRKYGQK] & $\mathrm{C}-\mathrm{X}_{4}-\mathrm{C}-\mathrm{X}_{22-23}-\mathrm{HXH}$ & $\mathrm{C}_{2} \mathrm{H}_{2}$ & 1 & 5 \\
\hline ZjWRKYY & XM_016020284.1 & 2205 & 734 & 80415.39 & 5.9 & $2 \times[$ WRKYGQK] & $\mathrm{C}-\mathrm{X}_{4}-\mathrm{C}-\mathrm{X}_{22-23}-\mathrm{HXH}$ & $\mathrm{C}_{2} \mathrm{H}_{2}$ & I & 1 \\
\hline ZjWRKY9 & $\underline{X M \_016029235.1}$ & 951 & 316 & 34758.07 & 8.44 & WRKYGQK & $\mathrm{C}-\mathrm{X}_{5}-\mathrm{C}-\mathrm{X}_{23}-\mathrm{HXH}$ & $\mathrm{C}_{2} \mathrm{H}_{2}$ & Ila & 4 \\
\hline ZjWRKY10 & XM_016014490.1 & 951 & 316 & 35076.43 & 8.68 & WRKYGQK & $\mathrm{C}-\mathrm{X}_{5}-\mathrm{C}-\mathrm{X}_{23}-\mathrm{HXH}$ & $\mathrm{C}_{2} \mathrm{H}_{2}$ & Ila & 5 \\
\hline ZjWRKY11 & $\underline{X M \_016028547.1}$ & 801 & 266 & 29844.33 & 8.99 & WRKYGQK & $\mathrm{C}-\mathrm{X}_{5}-\mathrm{C}-\mathrm{X}_{23}-\mathrm{HXH}$ & $\mathrm{C}_{2} \mathrm{H}_{2}$ & \|la & 4 \\
\hline ZjWRKY12 & $\underline{X M \_016022282.1}$ & 1863 & 620 & 67027.91 & 6.26 & WRKYGQK & $\mathrm{C}-\mathrm{X}_{5}-\mathrm{C}-\mathrm{X}_{23}-\mathrm{HXH}$ & $\mathrm{C}_{2} \mathrm{H}_{2}$ & $11 \mathrm{~b}$ & 5 \\
\hline ZjWRKY13 & XM_016029844.1 & 1902 & 633 & 67897.98 & 6.12 & WRKYGQK & $\mathrm{C}-\mathrm{X}_{5}-\mathrm{C}-\mathrm{X}_{23}-\mathrm{HXH}$ & $\mathrm{C}_{2} \mathrm{H}_{2}$ & $\| \mathrm{b}$ & 6 \\
\hline ZjWRKY14 & $\underline{\text { XM_016043879.1 }}$ & 1611 & 536 & 58692.78 & 6.48 & WRKYGQK & $\mathrm{C}-\mathrm{X}_{5}-\mathrm{C}-\mathrm{X}_{23}-\mathrm{HXH}$ & $\mathrm{C}_{2} \mathrm{H}_{2}$ & Ilb & 6 \\
\hline ZjWRKY15 & $\underline{\text { XM_016036346.1 }}$ & 1125 & 374 & 40424.14 & 8.09 & WRKYGQK & $\mathrm{C}-\mathrm{X}_{5}-\mathrm{C}-\mathrm{X}_{23}-\mathrm{HXH}$ & $\mathrm{C}_{2} \mathrm{H}_{2}$ & $11 \mathrm{~b}$ & 3 \\
\hline ZjWRKY16 & $\underline{\text { XM_016036345.1 }}$ & 1659 & 552 & 60686 & 7.71 & WRKYGQK & $\mathrm{C}-\mathrm{X}_{5}-\mathrm{C}-\mathrm{X}_{23}-\mathrm{HXH}$ & $\mathrm{C}_{2} \mathrm{H}_{2}$ & $\| \mathrm{b}$ & 7 \\
\hline ZjWRKY17 & $\underline{X M \_016037515.1}$ & 1512 & 503 & 56033.17 & 5.48 & WRKYGQK & $\mathrm{C}-\mathrm{X}_{5}-\mathrm{C}-\mathrm{X}_{23}-\mathrm{HXH}$ & $\mathrm{C}_{2} \mathrm{H}_{2}$ & $11 \mathrm{~b}$ & 5 \\
\hline ZjWRKY18 & XM_016039435.1 & 1251 & 416 & 44528.06 & 9.13 & WRKYGQK & $\mathrm{C}-\mathrm{X}_{5}-\mathrm{C}-\mathrm{X}_{23}-\mathrm{HXH}$ & $\mathrm{C}_{2} \mathrm{H}_{2}$ & Ilb & 3 \\
\hline ZjWRKY19 & $\underline{\text { XM_016014870.1 }}$ & 1878 & 625 & 67519.49 & 7.97 & WRKYGQK & $\mathrm{C}-\mathrm{X}_{5}-\mathrm{C}-\mathrm{X}_{23}-\mathrm{HXH}$ & $\mathrm{C}_{2} \mathrm{H}_{2}$ & $\| \mathrm{b}$ & 5 \\
\hline ZjWRKY2O & $\underline{\text { XM_016014977.1 }}$ & 1764 & 587 & 63426.84 & 8.8 & WRKYGQK & $\mathrm{C}-\mathrm{X}_{5}-\mathrm{C}-\mathrm{X}_{23}-\mathrm{HXH}$ & $\mathrm{C}_{2} \mathrm{H}_{2}$ & $\| \mathrm{b}$ & 4 \\
\hline ZjWRKY21 & $\underline{X M \_016014513.1}$ & 1878 & 625 & 67533.52 & 7.97 & WRKYGQK & $\mathrm{C}-\mathrm{X}_{5}-\mathrm{C}-\mathrm{X}_{23}-\mathrm{HXH}$ & $\mathrm{C}_{2} \mathrm{H}_{2}$ & $\| \mathrm{b}$ & 5 \\
\hline ZjWRKYZ22 & $\underline{X M \_016038792.1}$ & 579 & 192 & 21894.40 & 9.43 & WRKYGQK & $\mathrm{C}-\mathrm{X}_{4}-\mathrm{C}-\mathrm{X}_{23}-\mathrm{HXH}$ & $\mathrm{C}_{2} \mathrm{H}_{2}$ & Ilc & 2 \\
\hline ZjWRKY23 & $\underline{\text { XM_016040974.1 }}$ & 636 & 211 & 24030.21 & 8.47 & WRKYGQK & $\mathrm{C}-\mathrm{X}_{4}-\mathrm{C}-\mathrm{X}_{23}-\mathrm{HXH}$ & $\mathrm{C}_{2} \mathrm{H}_{2}$ & $\| c$ & 3 \\
\hline ZjWRKY24 & $\underline{\text { XM_016026686.1 }}$ & 597 & 198 & 22899.66 & 9.23 & WRKYGQK & $\mathrm{C}-\mathrm{X}_{4}-\mathrm{C}-\mathrm{X}_{23}-\mathrm{HXH}$ & $\mathrm{C}_{2} \mathrm{H}_{2}$ & Ilc & 2 \\
\hline ZjWRKY25 & $\underline{\text { XM_016014637.1 }}$ & 588 & 195 & 21527.72 & 6.73 & WRKYGKK & $\mathrm{C}-\mathrm{X}_{4}-\mathrm{C}-\mathrm{X}_{23}-\mathrm{HXH}$ & $\mathrm{C}_{2} \mathrm{H}_{2}$ & Ilc & 3 \\
\hline ZjWRKY26 & $\underline{X M \_016028953.1}$ & 522 & 173 & 19750.96 & 5.59 & WRKYGKK & $\mathrm{C}-\mathrm{X}_{4}-\mathrm{C}-\mathrm{X}_{23}-\mathrm{HXH}$ & $\mathrm{C}_{2} \mathrm{H}_{2}$ & Ilc & 3 \\
\hline ZjWRKY27 & $\underline{X M \_016011550.1}$ & 1008 & 335 & 37240.76 & 6.34 & WRKYGQK & $\mathrm{C}-\mathrm{X}_{4}-\mathrm{C}-\mathrm{X}_{23}-\mathrm{HXH}$ & $\mathrm{C}_{2} \mathrm{H}_{2}$ & Ilc & 4 \\
\hline ZjWRKY28 & $\underline{X M \_016024581.1}$ & 1038 & 345 & 39158.92 & 6.76 & WRKYGQK & $\mathrm{C}-\mathrm{X}_{4}-\mathrm{C}-\mathrm{X}_{23}-\mathrm{HXH}$ & $\mathrm{C}_{2} \mathrm{H}_{2}$ & IIc & 3 \\
\hline ZjWRKY29 & $\underline{X M \_016039492.1}$ & 933 & 310 & 34331.69 & 5.65 & WRKYGQK & $\mathrm{C}-\mathrm{X}_{4}-\mathrm{C}-\mathrm{X}_{23}-\mathrm{HXH}$ & $\mathrm{C}_{2} \mathrm{H}_{2}$ & Ilc & 3 \\
\hline ZjWRKY3O & $\underline{\text { XM_016011683.1 }}$ & 1110 & 369 & 40614.00 & 5.16 & WRKYGQK & $\mathrm{C}-\mathrm{X}_{4}-\mathrm{C}-\mathrm{X}_{23}-\mathrm{HXH}$ & $\mathrm{C}_{2} \mathrm{H}_{2}$ & Ilc & 3 \\
\hline ZjWRKY31 & $\underline{X M \_016036211.1}$ & 1008 & 335 & 37135.37 & 6.43 & WRKYGQK & $\mathrm{C}-\mathrm{X}_{4}-\mathrm{C}-\mathrm{X}_{23}-\mathrm{HXH}$ & $\mathrm{C}_{2} \mathrm{H}_{2}$ & IIC & 3 \\
\hline ZjWRKY32 & $\underline{\text { XM_016041473.1 }}$ & 756 & 251 & 28026.78 & 4.65 & WRKYGQK & $\mathrm{C}-\mathrm{X}_{4}-\mathrm{C}-\mathrm{X}_{23}-\mathrm{HXH}$ & $\mathrm{C}_{2} \mathrm{H}_{2}$ & Ilc & 2 \\
\hline ZjWRKY33 & XM_016028867.1 & 1116 & 371 & 40189.57 & 9.57 & WRKYGQK & $\mathrm{C}-\mathrm{X}_{5}-\mathrm{C}-\mathrm{X}_{23}-\mathrm{HXH}$ & $\mathrm{C}_{2} \mathrm{H}_{2}$ & $\| d$ & 3 \\
\hline ZjWRKY34 & $\underline{\text { XM_016011768.1 }}$ & 1101 & 366 & 39383.33 & 9.64 & WRKYGQK & $\mathrm{C}-\mathrm{X}_{5}-\mathrm{C}-\mathrm{X}_{23}-\mathrm{HXH}$ & $\mathrm{C}_{2} \mathrm{H}_{2}$ & Ild & 3 \\
\hline ZjWRKY35 & $\underline{X M \_016036017.1}$ & 1083 & 360 & 40498.69 & 9.65 & WRKYGQK & $\mathrm{C}-\mathrm{X}_{5}-\mathrm{C}-\mathrm{X}_{23}-\mathrm{HXH}$ & $\mathrm{C}_{2} \mathrm{H}_{2}$ & Ild & 4 \\
\hline ZjWRKY36 & $\underline{X M \_016045200.1}$ & 1497 & 498 & 53218.21 & 5.81 & WRKYGQK & $\mathrm{C}-\mathrm{X}_{5}-\mathrm{C}-\mathrm{X}_{23}-\mathrm{HXH}$ & $\mathrm{C}_{2} \mathrm{H}_{2}$ & lle & 3 \\
\hline ZjWRKY37 & XM_016020139.1 & 858 & 285 & 31393.44 & 5.62 & WRKYGQK & $\mathrm{C}-\mathrm{X}_{5}-\mathrm{C}-\mathrm{X}_{23}-\mathrm{HXH}$ & $\mathrm{C}_{2} \mathrm{H}_{2}$ & Ile & 3 \\
\hline ZjWRKY38 & $\underline{X M \_016025812.1}$ & 849 & 282 & 30475.83 & 5.46 & WRKYGQK & $\mathrm{C}-\mathrm{X}_{5}-\mathrm{C}-\mathrm{X}_{23}-\mathrm{HXH}$ & $\mathrm{C}_{2} \mathrm{H}_{2}$ & Ile & 3 \\
\hline ZjWRKY39 & XM_016022820.1 & 1422 & 473 & 51502.28 & 5.19 & WRKYGQK & $\mathrm{C}-\mathrm{X}_{5}-\mathrm{C}-\mathrm{X}_{23}-\mathrm{HXH}$ & $\mathrm{C}_{2} \mathrm{H}_{2}$ & lle & 3 \\
\hline ZjWRKY4O & $\underline{X M \_016044078.1}$ & 969 & 322 & 36328.33 & 8.98 & WRKYGQK & $\mathrm{C}-\mathrm{X}_{5}-\mathrm{C}-\mathrm{X}_{23}-\mathrm{HXH}$ & $\mathrm{C}_{2} \mathrm{H}_{2}$ & lle & 4 \\
\hline ZjWRKY41 & $\underline{X M \_016044080.1}$ & 1068 & 355 & 38920.61 & 5.92 & WRKYGQK & $\mathrm{C}-\mathrm{X}_{5}-\mathrm{C}-\mathrm{X}_{23}-\mathrm{HXH}$ & $\mathrm{C}_{2} \mathrm{H}_{2}$ & lle & 3 \\
\hline ZjWRKY42 & $\underline{X M \_016036213.1}$ & 870 & 289 & 32200.49 & 5.27 & WRKYGQK & $\mathrm{C}-\mathrm{X}_{5}-\mathrm{C}-\mathrm{X}_{23}-\mathrm{HXH}$ & $\mathrm{C}_{2} \mathrm{H}_{2}$ & Ile & 3 \\
\hline ZjWRKY43 & $\underline{X M \_016013400.1}$ & 1215 & 404 & 45202.30 & 6.64 & WRKYGQK & $\mathrm{C}-\mathrm{X}_{7}-\mathrm{C}-\mathrm{X}_{23}-\mathrm{HXC}$ & $\mathrm{C}_{2} \mathrm{HC}$ & III & 4 \\
\hline ZjWRKY44 & $\underline{\text { XM_016040779.1 }}$ & 1113 & 370 & 41825.52 & 5.26 & WRKYGQK & $\mathrm{C}-\mathrm{X}_{7}-\mathrm{C}-\mathrm{X}_{23}-\mathrm{HXC}$ & $\mathrm{C}_{2} \mathrm{HC}$ & III & 3 \\
\hline
\end{tabular}


Table 1 The information of WRKY gene family in Chinese jujube (Continued)

\begin{tabular}{|c|c|c|c|c|c|c|c|c|c|c|}
\hline Gene Name & NCBI Reference & ORF (bp) & Size (aa) & MW(D) & $\mathrm{PI}$ & Conserved motif & Domain pattern & Zinc finger & Group & Exon number \\
\hline ZjWRKY45 & XM_016022705.1 & 1176 & 391 & 43607.65 & 5.9 & WRKYGQK & $C-X_{7}-C-X_{23}-H X C$ & $\mathrm{C}_{2} \mathrm{HC}$ & III & 3 \\
\hline ZjWRKY46 & $\underline{\text { XM_016033893.1 }}$ & 1065 & 354 & 40462.32 & 5.16 & WRKYGQK & $\mathrm{C}-\mathrm{X}_{7}-\mathrm{C}-\mathrm{X}_{23}-\mathrm{HXC}$ & $\mathrm{C}_{2} \mathrm{HC}$ & III & 4 \\
\hline ZjWRKY47 & XM_016041850.1 & 960 & 319 & 36005.79 & 5.25 & WRKYGQK & $\mathrm{C}-\mathrm{X}_{7}-\mathrm{C}-\mathrm{X}_{23}-\mathrm{HXC}$ & $\mathrm{C}_{2} \mathrm{HC}$ & III & 3 \\
\hline ZjWRKY48 & $\underline{X M \_016013401.1}$ & 1035 & 344 & 38711.93 & 5.39 & WRKYGQK & $\mathrm{C}-\mathrm{X}_{7}-\mathrm{C}-\mathrm{X}_{23}-\mathrm{HXC}$ & $\mathrm{C}_{2} \mathrm{HC}$ & III & 3 \\
\hline ZjWRKY49 & XM_016041861.1 & 981 & 326 & 37477.17 & 8.15 & WRKYGQK & $\mathrm{C}-\mathrm{X}_{7}-\mathrm{C}-\mathrm{X}_{23}-\mathrm{HXC}$ & $\mathrm{C}_{2} \mathrm{HC}$ & III & 3 \\
\hline ZjWRKY50 & $\underline{X M \_016041806.1}$ & 930 & 309 & 35609.87 & 5.91 & WRKYGQK & $\mathrm{C}-\mathrm{X}_{7}-\mathrm{C}-\mathrm{X}_{23}-\mathrm{HXC}$ & $\mathrm{C}_{2} \mathrm{HC}$ & III & 3 \\
\hline ZjWRKY51 & $\underline{\text { XM_016047371.1 }}$ & 924 & 307 & 35268.77 & 6.71 & WRKYGQK & $\mathrm{C}-\mathrm{X}_{7}-\mathrm{C}-\mathrm{X}_{23}-\mathrm{HXC}$ & $\mathrm{C}_{2} \mathrm{HC}$ & III & 3 \\
\hline ZjWRKY52 & $\underline{\text { XM_016041801.1 }}$ & 948 & 315 & 35731.33 & 6.46 & WRKYGQK & $\mathrm{C}-\mathrm{X}_{7}-\mathrm{C}-\mathrm{X}_{23}-\mathrm{HXC}$ & $\mathrm{C}_{2} \mathrm{HC}$ & III & 3 \\
\hline ZjWRKY53 & $\underline{\text { XM_016041802.1 }}$ & 972 & 323 & 37104.55 & 8.78 & WRKYGQK & $\mathrm{C}-\mathrm{X}_{7}-\mathrm{C}-\mathrm{X}_{23}-\mathrm{HXC}$ & $\mathrm{C}_{2} \mathrm{HC}$ & III & 3 \\
\hline ZjWRKY54 & $\underline{X M \_016041803.1}$ & 951 & 316 & 36421.82 & 5.76 & WRKYGQK & $\mathrm{C}-\mathrm{X}_{7}-\mathrm{C}-\mathrm{X}_{23}-\mathrm{HXC}$ & $\mathrm{C}_{2} \mathrm{HC}$ & III & 3 \\
\hline
\end{tabular}

ZjWRKY gene was found on Chr. 7. Additionally, the gene structure was highly conserved within each group, especially in groups IId, IIe, and III. We found that Group I genes contained more introns and were more complicated than genes in the other two groups (Fig. 4). Tandem duplications were present in $40.7 \%$ of $Z j W R K Y$ genes (ZjWRKY1, 15, 16, 18, 26, 29, 31, 33, 35, 39, 40, $41,42,45,47,49,50,52,53$, and 54), which contributed to the expansion of the ZjWRKY gene family. This dynamic was particularly evident in Group III in which 8 out of the 12 genes (66.7\%) mapped to duplicated chromosome or scaffold regions.

\section{Expression profiles of ZjWRKYs in various tissues/organs}

To investigate the tissue-specific expression of the jujube WRKY genes, RT-PCR was used to determine their expression patterns in seven tissues. The expression patterns of $26 Z j W R K Y$ genes were analysed and are shown in Fig. 5a. Of the $26 \mathrm{ZjWRKY}$ genes, six genes were actively expressed in at least five tissues, including $Z j W R K Y 6,9,10,13,29$, and 42. A total of $8 Z j W R K Y$ genes (ZjWRKY2, 22, 25, 33, 36, 44, 45 and 48) were found to be upregulated in only one or two tissues, indicative of the tissue-specific expression of these genes. $Z j W R K Y 24$ expression could only be detected in roots and old branches. The expression of the remaining genes was comparatively low in the different organs, suggesting that genes in the same group might have different functions. These results showed that most of the $Z j W R K Y$ genes had diverse tissue-specific expression patterns, indicating that $Z j W R K Y s$ play multiple roles in various organs.

Moreover, a heat map of our RNA-Seq data highlighted differential expression of $Z j W R K Y s$ during jujube fruit development (Fig. 5b), and most of the genes were expressed at different levels. The genes of group IIe were mainly expressed at before white mature period (BWM) and white mature period (WM), and the expression of group IIb genes was lower at young fruit period (Y) except for
ZjWRKY13. ZjWRKY8, 26, 47, and 48 were only involved in the development of young fruit, suggesting the role for these WRKY genes in jujube fruit development.

\section{ZjWRKYs involved in the jujube-phytoplasma interaction}

The expression of the phytoplasma TMK gene was not detected in the healthy leaves, however its highly expression was found in other diseased tissues, including the apparently normal leaves (Additional file 4). Among the 30 ZjWRKY genes detected, 17 ZjWRKYs (ZjWRKY2, 3, $6,9,10,15,18,22,24,26,34,36,37,38,42,44$, and 45$)$ were significantly upregulated under phytoplasma stress, while $5 \mathrm{ZjWRKYs}(Z j W R K Y 5,8,33,47$, and 49) were downregulated (Fig. 6a). The expression of ZjWRKY32 first increased and then decreased in diseased jujube. Most Group II genes were upregulated under phytoplasma stress. ZjWRKY37, ZjWRKY38, and ZjWRKY44 were significantly upregulated in phyllody leaves. ZjWRKY5 and ZjWRKY49 were significantly downregulated in diseased leaves. These ZjWRKY genes displayed noticeable changes in expression and should play vital roles in jujube-phytoplasma interactions.

STRING analysis displayed that WRKY proteins could function by interacting with each other, as well as with MPK3 (Additional file 7A). Furtherly, yeast two-hybrid screening proved that ZjWRKY9 and ZjWRKY37 were interacting with ZjMAPKK6 (Fig. 6b), and ZjWRKY26 was interacting with ZjMAPKK2 (Fig. 6c). In previous study, it was found that ZjMAPKs and ZjMAPKKs were also involved in phytoplasma infection [28].

To confirm the identities of these ZjWRKY genes for phytoplasma tolerance, we analysed the transcript profiles of $Z j W R K Y$ genes in a JWB-resistant variety and a susceptible variety (Fig. 7). The detection of the phytoplasma in the two varieties was shown in Additional file 4. After phytoplasma infection, the expression of $9 \mathrm{ZjWRKYs}$ (ZjWRKY2, $9,22,24,29,34,36,42$, and 45) in the susceptible variety were higher than in the resistant variety, and they were also upregulated in above diseased tissues (Fig. 6). In contrast, 


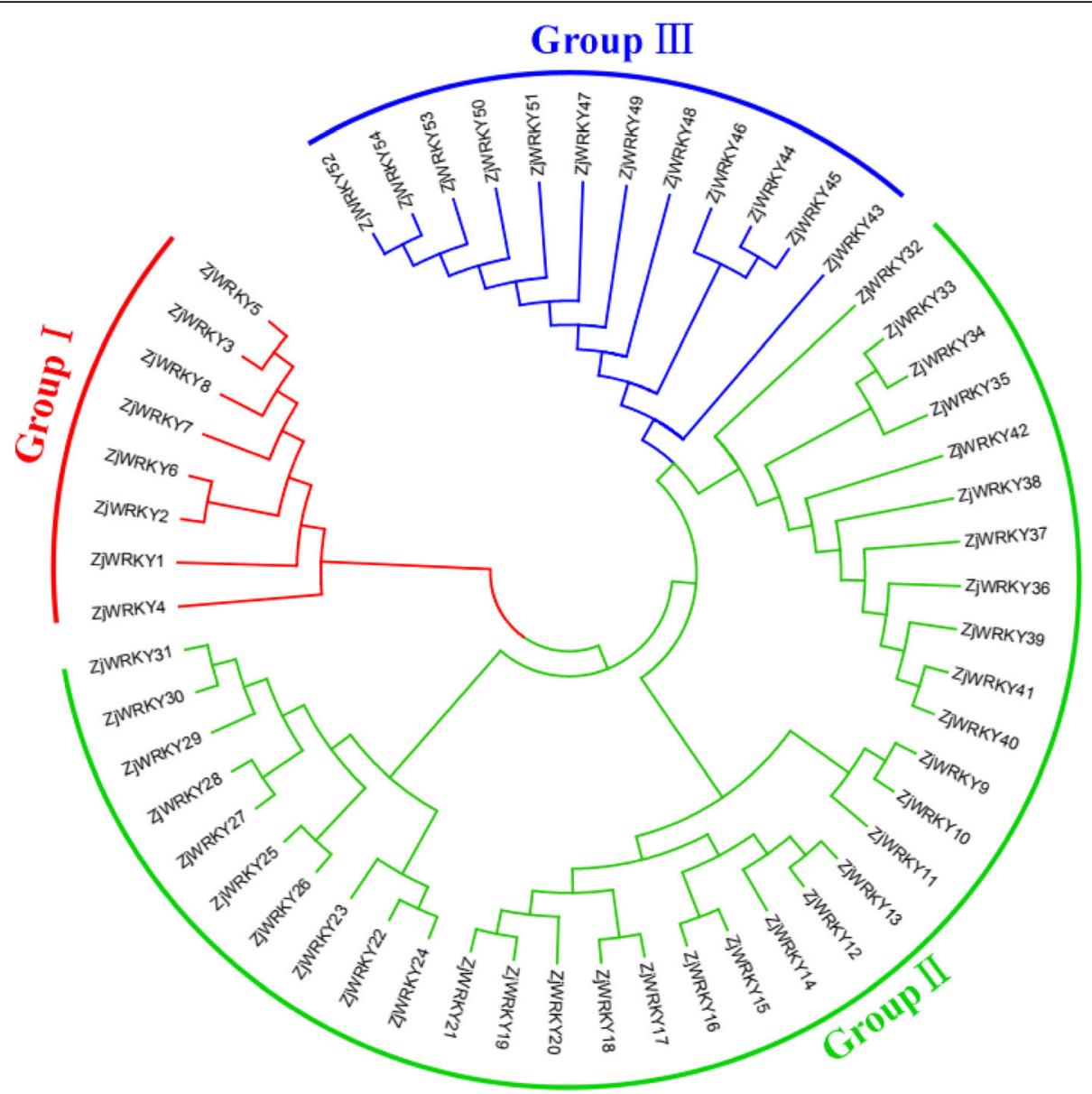

Fig. 1 The phylogenetic tree of the ZjWRKY proteins. The NJ tree was constructed from the amino acid sequences of ZjWRKYS using MEGA5.2 with 1000 bootstrap replicates

the expression of ZjWRKY5 and ZjWRKY49 in the resistant variety was higher than in the susceptible one during the early stages of infection. These two genes were significantly downregulated in diseased tissues. ZjWRKY4 expression in the resistant variety was also higher than in the susceptible one. The above results indicated that some ZjWRKYs might play a role in phytoplasma tolerance.

\section{Discussion}

In this study, a total of 54 WRKY-encoding genes were identified in the jujube genome. These genes can be can be divided into three groups (Group I to III), but this number may increase in the future once problems with the assembly and annotation of the jujube genome are addressed. As in other plants, almost all of the ZjWRKY genes share the WRKYGQK signature motif. However, the WRKYGKK variant was found in two jujube genes (Table 1, Fig. 2). Such slight variations in this region have also been reported in other plants such as Arabidopsis and apple [29].
Gene duplication events are the biggest contributors to the rapid expansion and evolution of gene families. Previous research has demonstrated that the Arabidopsis Group III WRKY gene family expanded rapidly as a result of recent segmental and tandem duplication events [30], and we found that this was also the case in the jujube genome. There are 6 tandemly duplicated $Z j W R K Y$ genes (ZjWRKY47, ZjWRKY49, ZjWRKY50, ZjWRKY52, $Z j W R K Y 53$, and $Z j W R K Y 54)$ in Group III. The phylogenetic analysis (Additional file 5) indicated that 6 Group III ZjWRKYs were grouped and then clustered with 6 other genes from Arabidopsis; this also occurred in other subgroups from apple and pear. This finding suggests that the duplications in Group III WRKY genes occurred after the divergence of these plant species and tandem duplication events are the main contributors to the expansion of the Group III genes.

Previous research has demonstrated that Group I WRKY genes are the ancestors of the other WRKY genes in plants and are more likely to be constitutively expressed in different tissues [30]. In our study, the 


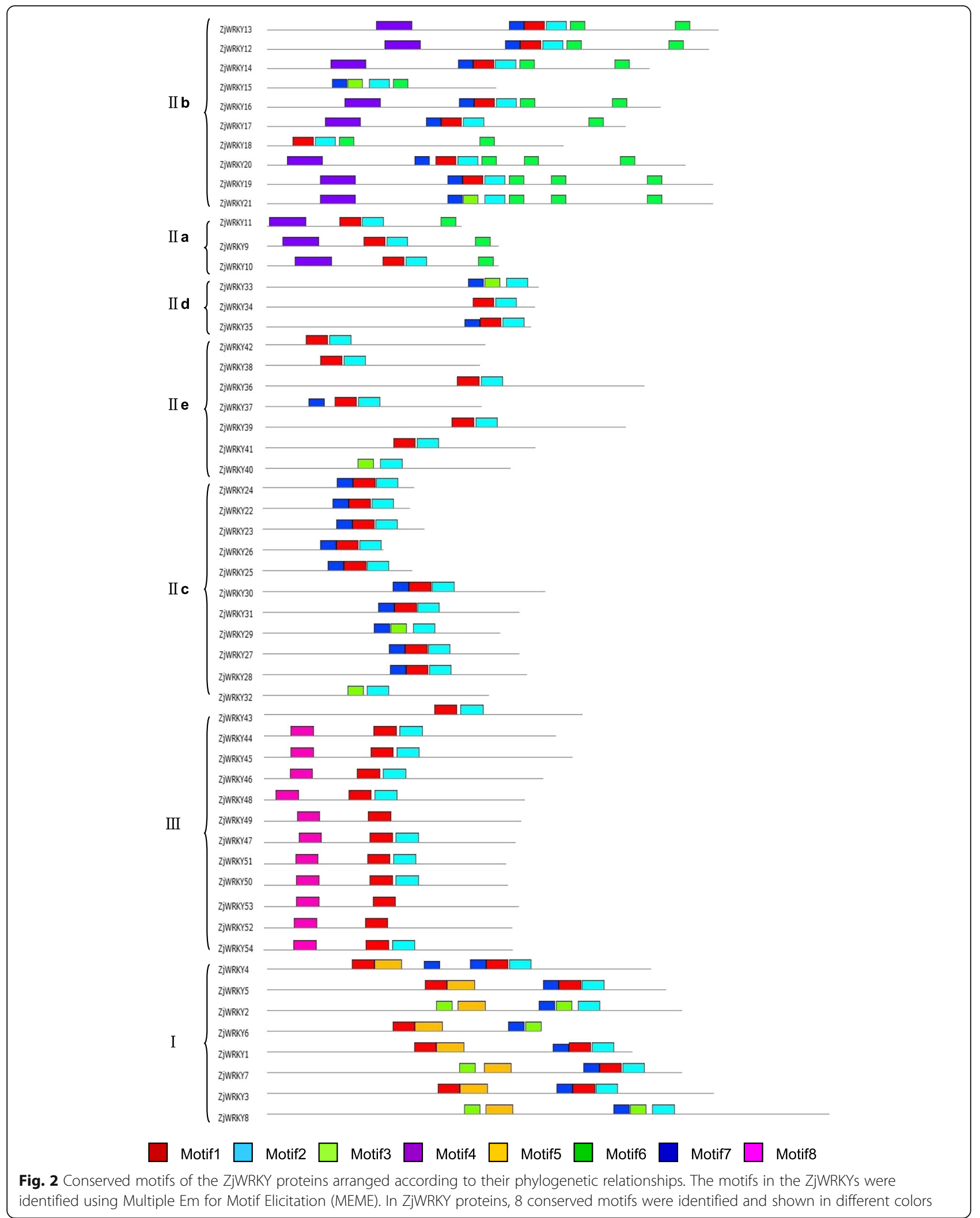




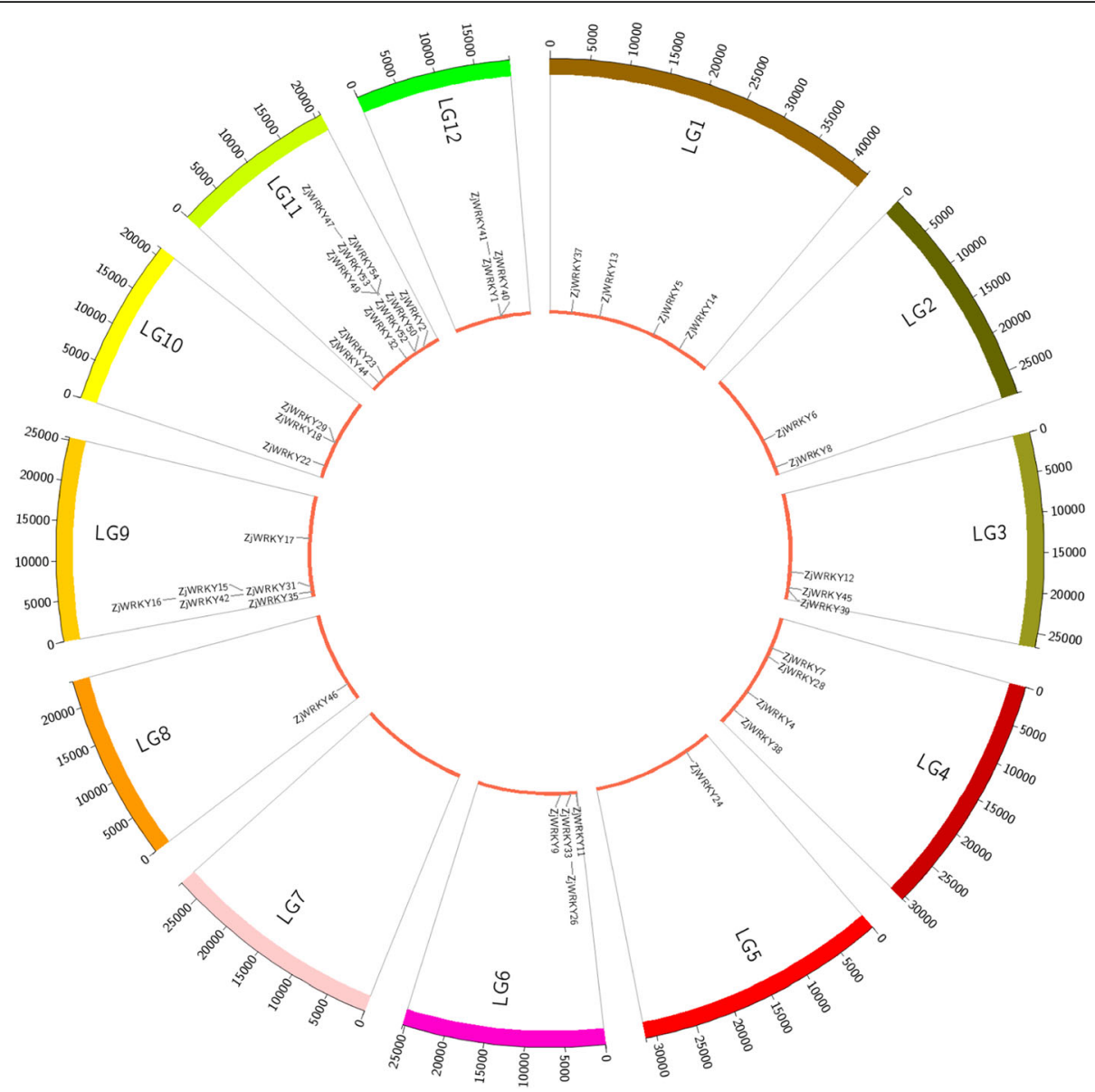

Fig. 3 Positions of 41 ZjWRKY genes on the jujube chromosomes. Genes were mapped to the jujube chromosomes via the Circos tool. The jujube chromosomes were arranged in a circle

Group I genes and many genes from the other two groups were expressed in various tissues (Fig. 5), indicative of their diverse functions. These results provide some useful clues for additional investigations into the biological functions of these WRKY genes in jujube growth and development.

Transgenic apple lines overexpressing MdWRKY9 were significantly shorter and had significantly lower internode lengths than control plants [31], and its two orthologues in Arabidopsis (AtWRKY11 and AtWRKY17) are negative regulators of basal resistance to a bacterial pathogen [32-34]. The Group II phylogenetic tree (Fig. 8) indicates that AtWRKY11, 17, and ZjWRKY34 are closely related. In this study, we found that ZjWRKY34 was expressed at a noticeably higher level in infected jujube (Fig. 6) and in the JWB-resistant variety than in the susceptible variety at later stages of infection. STRING analysis showed that ZjWRKY34 (the orthologous of AtWRKY17) can interact with MSK1 and calmodulin (CAM, Fig. 9b). MKS1 is a regulator of plant defense response and it may contribute to MPK4-regulated defense activation by coupling the kinase to specific WRKY transcription factors. It also indicated that ZjWRKY34 might interact with the calmodulin- $\mathrm{Ca}^{2+}$ complex. Inferring the potential functions of $Z j W R K Y 34$ from the known AtWRKYs suggests that ZjWRKY34 might also act as a negative regulator in the defence process during jujube-phytoplasma interactions.

$Z j W R K Y 9$ was actively expressed in JWB-diseased tissues. The phylogenetic tree (Fig. 8) and sequence alignment showed that $Z j W R K Y 9$ was the orthologous gene of AtWRKY18. Transgenic AtWRKY18 plants had increased expression of pathogenesis-related genes and resistance to the bacterial pathogen Pseudomonas syringae, indicating that AtWRKY18 can positively modulate defence-related gene expression and disease resistance [12]. AtWRKY18/40 act in a feedback repression system controlling basal defences [10]. In the other side, high AtWRKY18 expression can cause severely abnormal plant growth [12]. These results suggest that proper expression of $Z j W R K Y 9$ is critical for enhancing jujube's defence response without negatively impacting plant growth. ZjWRKY9's higher expression might be related 


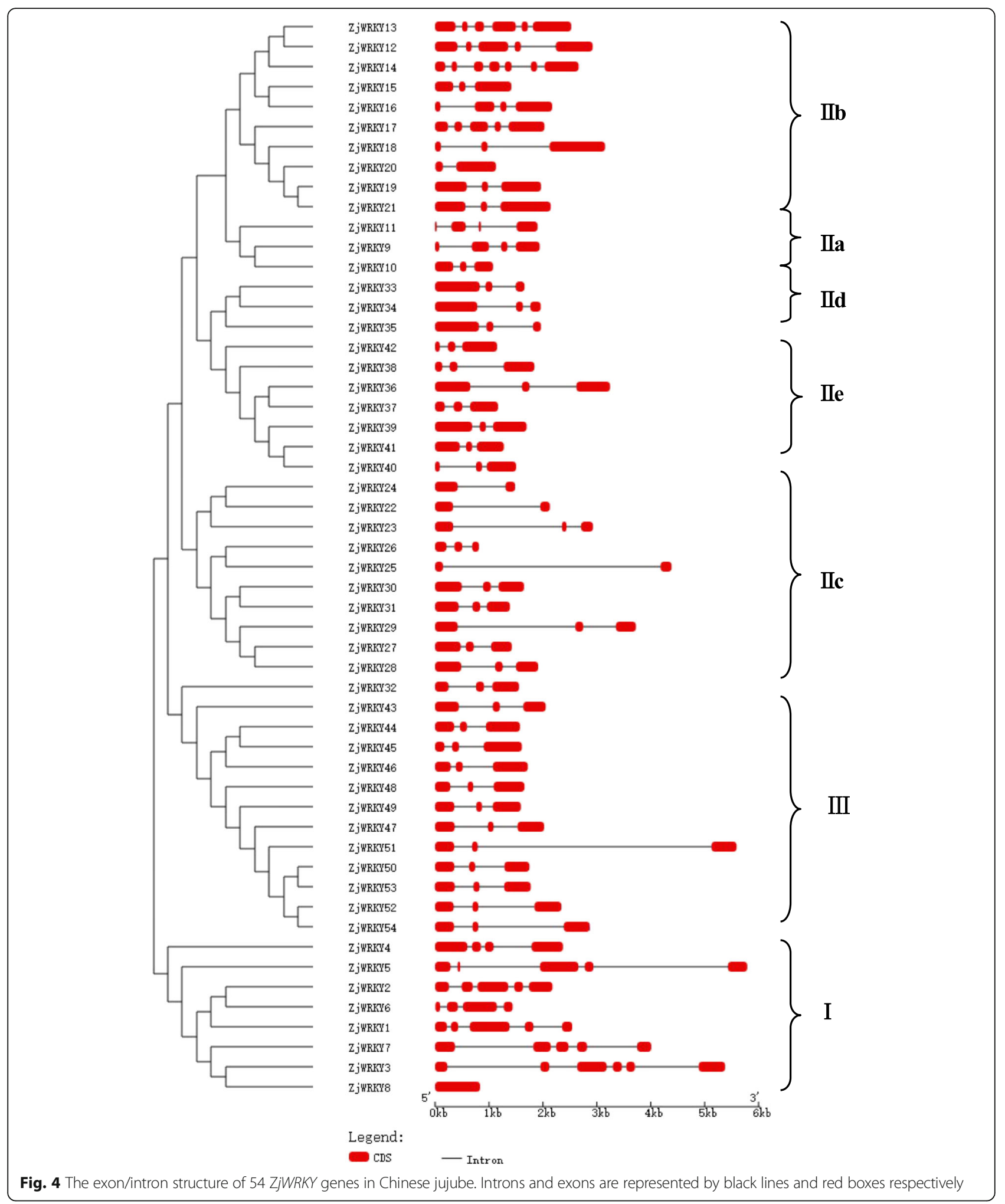

to the abnormal growth of diseased jujube trees, such as witches' broom and tiny leaves.

Overexpression of AtWRKY28 and AtWRKY75 induced an oxidative burst in host plants, which suppressed the hyphal growth of Sclerotinia sclerotiorum and consequently inhibited fungal infection [35]. STRING analysis predicted that AtWRKY75 could interact with GSTU10 (Fig. 9), which can 


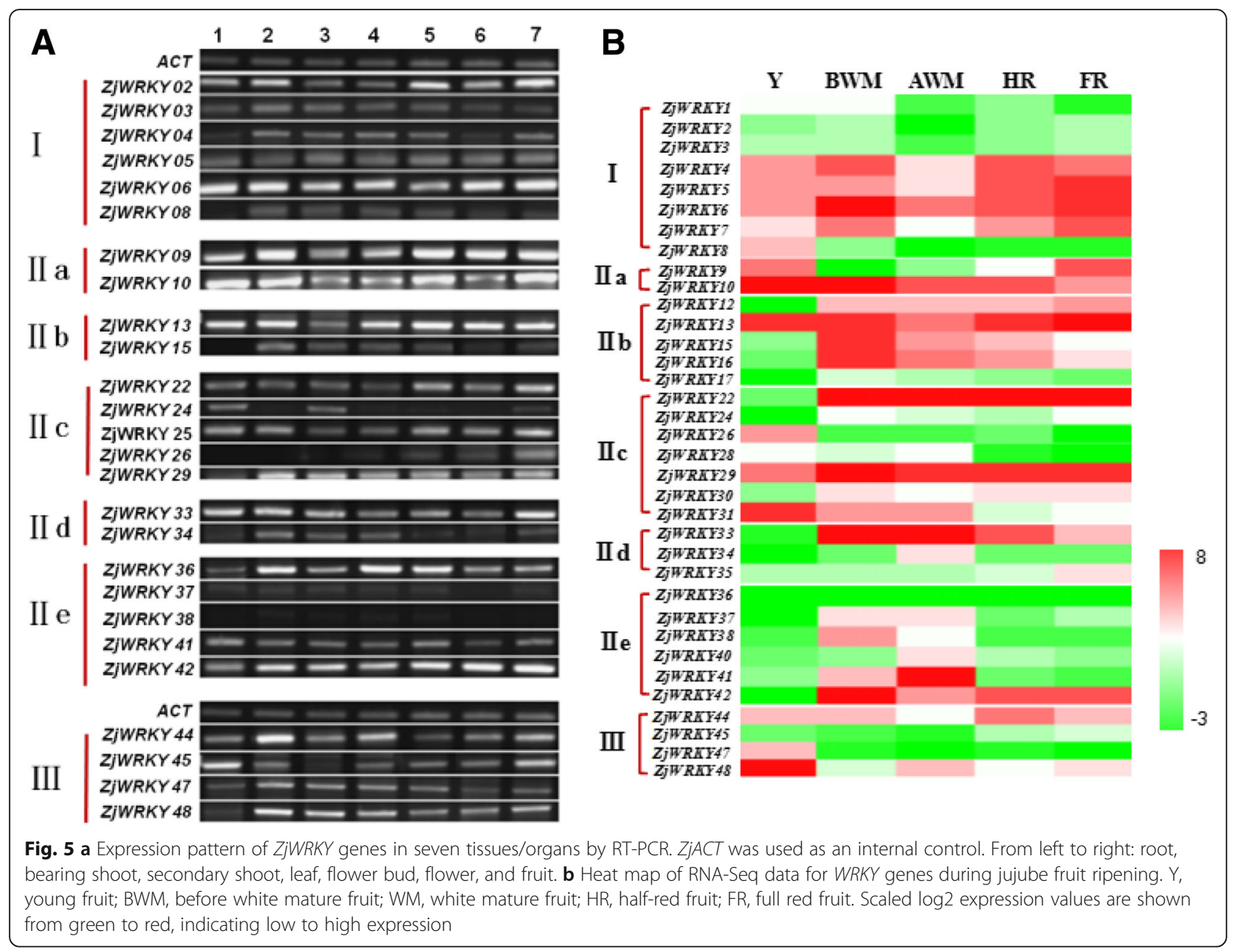

eliminate the toxicity of oxygen bursts on plant cells and increase plant tolerance [36]. In this study, ZjWRKY22 and $Z j W R K Y 24$ are orthologous of AtWRKY75 (Fig. 8), which behaved higher expression in the susceptible variety than in the resistant one (Fig. 7). That means that the two genes might eliminate the toxicity of oxygen bursts caused by phytoplasma infection. Previous study also indicated that the expression of WRKY gene was responsive to phytoplasma infection [37]. A divergent behaviour was previously observed for OsWRKY28. In rice, overexpression of OsWRKY28 enhanced susceptibility to the rice blast fungus Magnaporthe oryzae and decreased accumulation of PR5 [38]. The knock-out of OsWRKY28 led to a two-fold increase in resistance to a compatible rice blast fungus and this phenotype is accompanied by the increased expression of several defence-related genes [39]. Hence, OsWRKY28 acts as a negative regulator of basal defence responses. Similarly, some WRKY genes might act as negative regulators of the basal resistance of jujube under phytoplasma stress, but further study is necessary to verify their specific functions.

\section{Conclusions}

This paper described the WRKY gene family of Chinese jujube at the genome level. Their gene structure, chromosomal distribution, phylogenetic relationship, and tissue-specific expression patterns were presented in this study. Most of the ZjWRKYs were positive responses to phytoplasma invasion, and that provided meaningful candidates for the future studies of $Z j W R K Y s$ involved in jujube-phytoplasma interaction.

\section{Methods}

\section{Plant material}

The seven tissues including roots, young branches, old branches, leaves, flower buds, flowers and young fruits were collected from three jujube trees and used for organ-specific expression analysis.

Four kinds of tissues representing different degrees of JWB disease (apparently normal leaves (ANL), phyllody leaves (PL), and witches'-broom leaves (WBL)) from diseased trees, and healthy leaves (HL) from healthy trees were collected at four growth periods (June, July, 


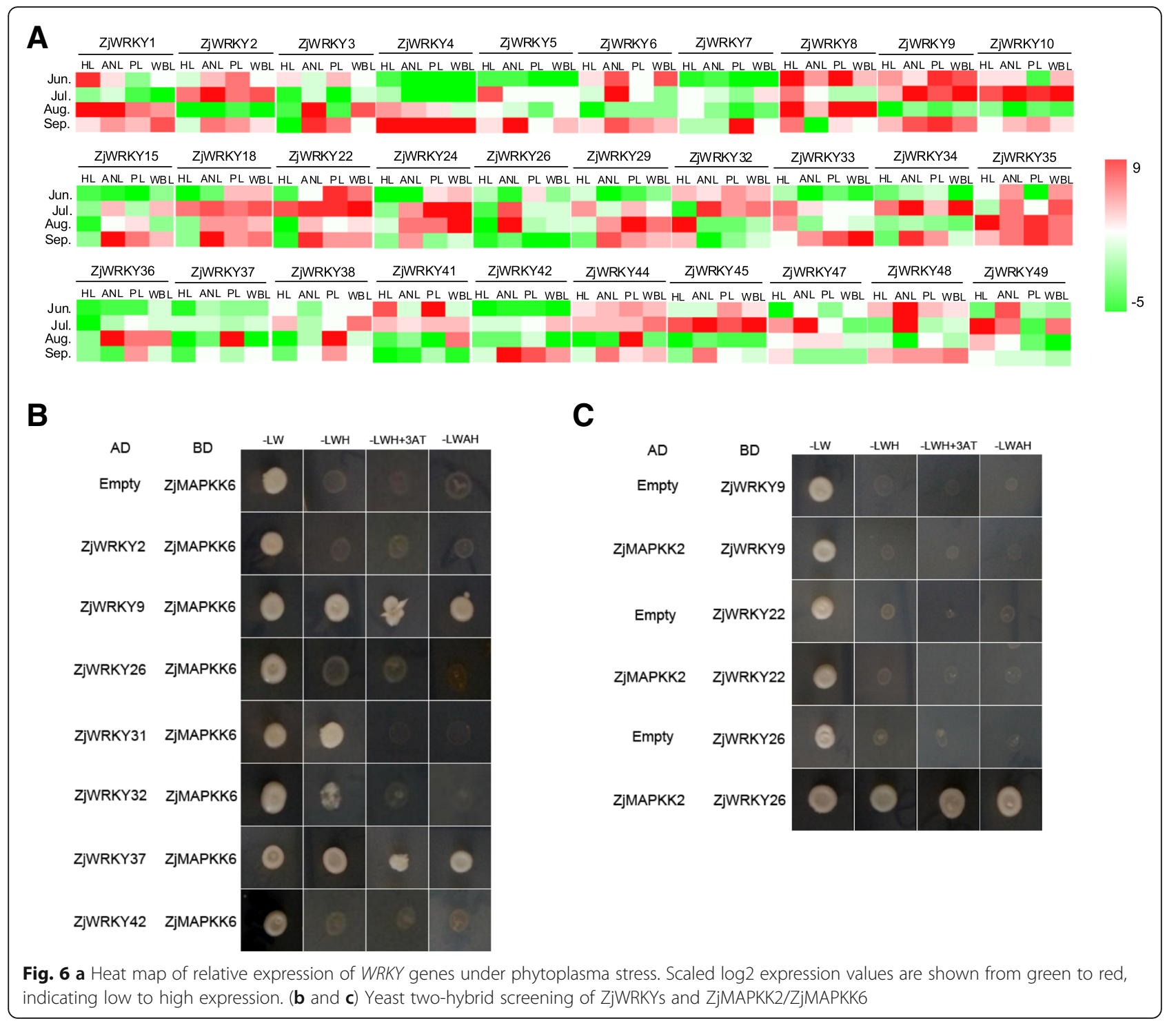

August, and September). The All treatments were conducted with three biological replicates.

Phytoplasma cannot be cultured in vitro, and thus, JWB phytoplasma infection was transmitted by grafting. A JWB-resistant variety and a susceptible variety were used as scions for grafting onto JWB-diseased and healthy trees. All grafting treatments were conducted with three replicates. The samples were collected from sprouted scions at five growth periods (June, July, August, September and October). The samples were stored at $-80{ }^{\circ} \mathrm{C}$ until RNA extraction and expression analysis.

The JWB phytoplasma presence of the samples was detected by quantitative real-time PCR (qRT-PCR) [40]. The expression of phytoplasma TMK gene in jujube samples was analysed and $\mathrm{ZjACT}$ was used as an internal control.

\section{Identification and protein structure analysis of ZjWRKYs} in Chinese jujube

First, WRKY genes from Arabidopsis were used as queries to search the jujube genome database. Next, the Pfam (http://pfam.xfam.org/) and SMART (http://smart.emblheidelberg.de/) databases were used to confirm the predicted jujube WRKY proteins. To further confirm that the amino acid sequences in our data set were WRKYs, we manually examined the conserved WRKYGQK amino acid motif at the N-terminus and the zinc-finger-like motif at the $\mathrm{C}$-terminus of the predicted WRKY domain. Truncated and false genes were excluded from our analysis. The number of amino acids, molecular weight, and theoretical pI of ZjWRKY genes were predicted by Protparam (https://web.expasy.org/ compute_pi/). The conserved motifs of ZjWRKY proteins were detected by MEME (http://meme-suite.org/), 


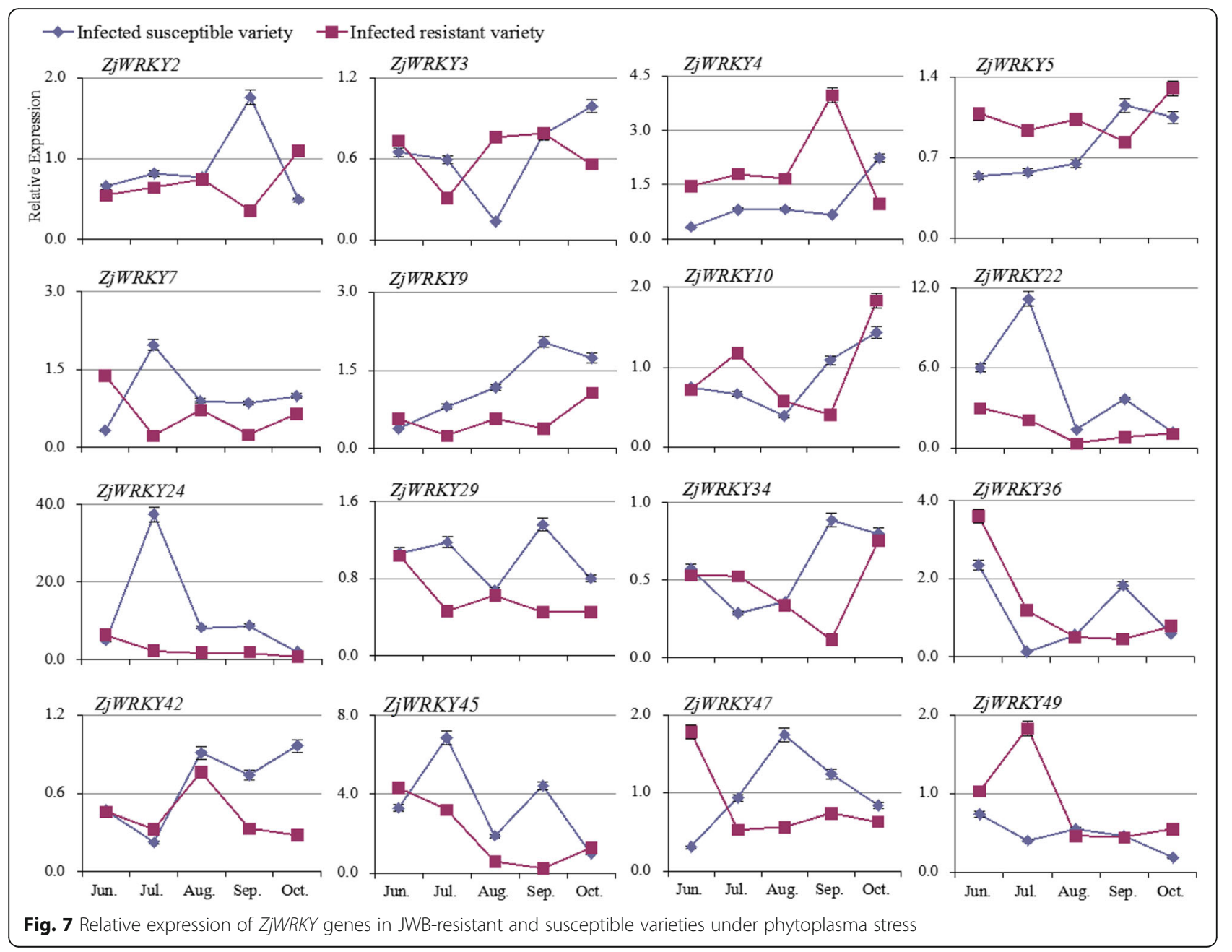

using the following parameters: number of repetitions, any; maximum number of motifs, 20; and the optimum motif widths, 6-60 amino acid resides [41].

The chromosomal location and gene structure of ZjWRKYs To determine the chromosomal location of the $Z j W R K Y$ genes, their gene sequences were used as query sequences in BLASTN searches against the jujube genome. Each $Z j W R K Y$ gene was mapped to the jujube genome according to their genome coordinates. Tandem duplications were identified as previously described [42].

The website GSDS (http://gsds.cbi.pku.edu.cn/) was used to predict the number of exons from the coding domain sequences (CDS) and DNA sequences of the WRKY genes [43].

\section{Multiple sequence alignment and phylogenetic tree construction}

The jujube WRKY proteins were classified into different groups based on their conserved domains. A phylogenetic tree was constructed from the amino acid sequences of
WRKY conserved domains from jujube (54 sequences). The Arabidopsis thaliana WRKY proteins were retrieved from the TAIR database (http://www.arabidopsis.org/) as reported previously. Additionally, WRKY proteins of three other species (Persica prunus [22], Pyres bretschneideri [21], and Malus domestica [29]) were downloaded from NCBI. The classification of jujube Group II WRKY genes using the phylogenetic tree was dependent on the putative Arabidopsis thaliana orthologs. The MEGA 5.2 software and the neighbour-joining statistical method were used to construct a rooted phylogenetic tree [44-46]. The evolutionary distances were obtained using the p-distances method, and these distances were used to estimate the number of amino acid substitutions per site. The reliability of each phylogenetic tree was established by conducting 1000 bootstrap sampling iterations.

\section{RNA isolation and expression and statistical analysis}

Total RNA was extracted using an RNAprep Pure Plant Kit (TIANGEN) according to the manufacturer's protocol. 


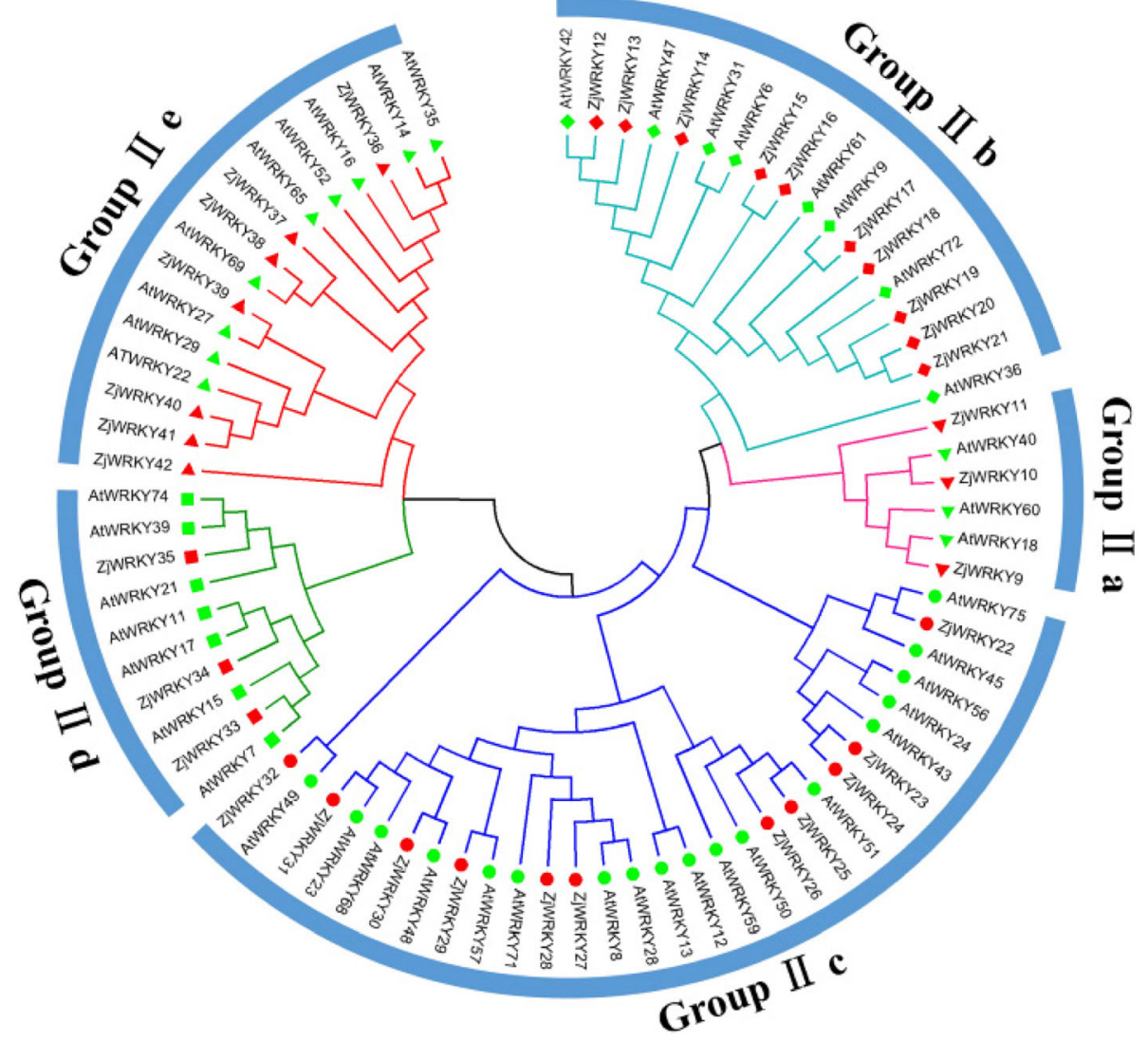

Fig. 8 Phylogenetic relationships of Groupll WRKY genes from Chinese jujube and Arabidopsis

After genomic DNA was removed by RNase-free DNase I (TIANGEN), RNA concentration and purity were checked on a NanoDrop2000 spectrophotometer. First-strand cDNA was synthesized by reverse transcribing $500 \mathrm{ng}$ of total RNA with FastQuant RT Super Mix Kit (TIANGEN). The cDNA was used as the template for qRT-PCR.

Gene expression was detected by qRT-PCR. The primers used in this study are listed in Additional file 6.
PCR products were amplified in triplicate using the Bio-Rad $\mathrm{iQ}^{\mathrm{mm}} 5$ with TransStart Top Green qPCR SuperMix AQ131 (TransGen Biotech, China) in $20 \mu \mathrm{L}$ reactions. Each reaction contained $10 \mu \mathrm{L}$ of $2 \times$ TransStart $^{\circ}$ Top Green qPCR SuperMix, $0.4 \mu \mathrm{L}$ each of $10 \mu \mathrm{M}$ primers, $8.2 \mu \mathrm{L}$ of $\mathrm{ddH}_{2} \mathrm{O}$ and $1 \mu \mathrm{L}$ of cDNA. The thermal profile for RT-qPCR was as follows: preincubation for $30 \mathrm{~s}$ at $95{ }^{\circ} \mathrm{C}$, followed by 40 cycles of $5 \mathrm{~s}$ at $95{ }^{\circ} \mathrm{C}$,

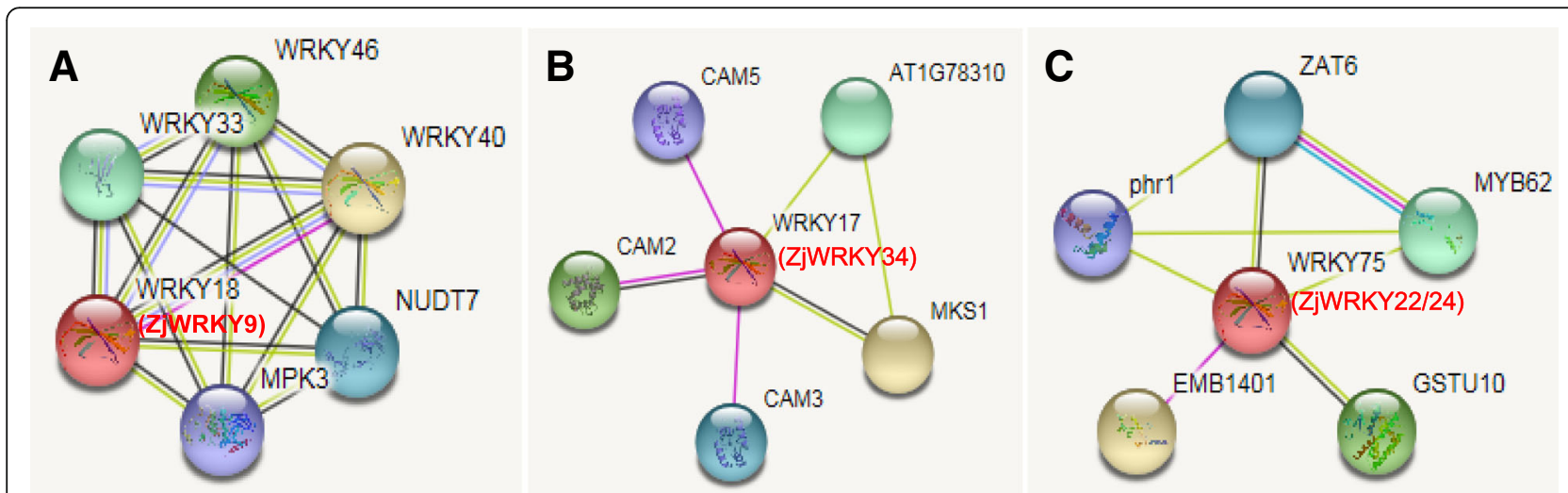

Fig. 9 The protein-protein interaction analysis of ZjWRKY9, ZjWRKY34, ZjWRKY22 and ZjWRKY24 by STRING database. a ZjWRKY9 is the orthologous of AtWRKY18; b ZjWRKY34 is the orthologous of AtWRKY17; c ZjWRKY22 and ZjWRKY24 were the orthologous of AtWRKY75 
$10 \mathrm{~s}$ at $53-58{ }^{\circ} \mathrm{C}$, and $10 \mathrm{~s}$ at $72{ }^{\circ} \mathrm{C}$. Three biological replicates were performed for each treatment. Threshold cycle values were calculated using iCycler software, and $Z j A C T$ was used as an internal control [47]. Relative transcript levels were calculated according to the $2^{-\Delta \Delta C T}$ method [48].

\section{Yeast two-hybrid screening (Y2H)}

ZjWRKY protein is fused to the Gal4 DNA-binding domain (BD) and the screening proteins are fused to the Gal4 activation domain (AD). The AD-fused ZjWRKY and BD-fused ZjMAPK were amplified using the primers shown in Supplementary Table S1, and cloned into the pGADT7 vector and pGBKT7 respectively. ZjWRKYs were digested by SmaI and the ZjMAPKs were digested by EcoRI and co-transformed AH109 stain with pairs of appropriate pGADT7 and pGBKT7 vectors. Successful co-transformants were selected on synthetically defined medium lacking tryptophan and leucine (SD/-Trp/-Leu). To examine protein-protein interactions, freshly transformed yeast colonies were resuspended in $10 \mu \mathrm{L}$ sterile deionized water, and $0.5 \mu \mathrm{L}$ aliquots were spotted upon medium lacking leucine and tryptophan (-LW) and medium lacking leucine, tryptophan, histidine $(-\mathrm{LWH})$, supplemented with $7 \mathrm{mM}$ 3-Amino-1,2,4-triazole (3-AT; Sigma Aldrich) (-LWH + 3AT) and medium lacking leucine, tryptophan, histidine, adenine (-LWAH). Growth was scored after $3 \mathrm{~d}$ of incubation at $28^{\circ} \mathrm{C}$.

\section{Additional files}

\section{Additional file 1: Number of WRKY gene family from Chinese jujube} and other species (DOC $28 \mathrm{~kb}$ )

Additional file 2: The amino acid sequences of 8 motifs among ZjWRKY proteins. (DOC $160 \mathrm{~kb}$ )

Additional file 3: Positions of 13 ZjWRKY genes on the jujube scaffolds. The jujube scaffolds were arranged in a circle. (DOC $319 \mathrm{~kb}$ )

Additional file 4: Expression analysis of phytoplasma TMK in four kinds of leaves (A) and in susceptible and resistant varieties (B). (DOC $31 \mathrm{~kb}$ )

Additional file 5: The phylogenetic analysis of Group III WRKYs of Ziziphus jujuba, Arabidopsis thaliana, Pyres Bretschneideri, Persica Prunus and Malus domestica. (DOC $89 \mathrm{~kb}$ )

Additional file 6: The primers of ZjWRKY genes used in this study. (DOC $36 \mathrm{~kb}$ )

\section{Abbreviations}

ANL: Apparently normal leaves; CDS: Coding domain sequences; HL: Healthy leaves; JWB: Jujube witches' broom disease; PL: Phyllody leaves; qRTPCR: Quantitative real-time PCR; TFs: Transcription factors; WBL: Witches'broom leaves

\section{Acknowledgements}

Not applicable.

\section{Funding}

Supported by the National Key R\&D Program Project Funding (2018YFD1000607), the National Natural Science Foundation of China (31772285), and Hebei Distinguished Young Scholar (C2016204145). These funding bodies had no role in the design of the study, sample collection, analysis or interpretation of data and in writing the manuscript.

Availability of data and materials

All data and materials are presented in the main paper and additional supporting file.

\section{Authors' contributions}

$J Z$ and $M L$ designed the research; $C X, H L$ and JZ performed the experiments, analyzed the data and wrote the paper. ZL, LW and HF participated in the data analysis. YZ and XW performed RT-PCR, RT-qPCR experiments. All authors read and approved the final the manuscript

\section{Ethics approval and consent to participate}

Chinese jujube is one of widespread fruit trees in China, and it is not an endangered species. The healthy and diseased jujube trees were from the Experimental Station of Chinese Jujube, Hebei Agricultural University. No specific permits are required for sample collection on Chinese jujube.

\section{Consent for publication}

Not applicable.

\section{Competing interests}

The authors declare that they have no competing interests.

\section{Publisher's Note}

Springer Nature remains neutral with regard to jurisdictional claims in published maps and institutional affiliations.

\section{Author details}

${ }^{1}$ College of Life Science, Hebei Agricultural University, Baoding, China. ${ }^{2}$ Key Laboratory of Hebei Province for Plant Physiology and Molecular Pathology, Hebei Agricultural University, Baoding, Hebei, China. ${ }^{3}$ Research Center of Chinese Jujube, Hebei Agricultural University, Baoding, China. ${ }^{4}$ BGI-Shenzhen, Shenzhen, China.

Received: 28 January 2019 Accepted: 9 May 2019

Published online: 07 June 2019

\section{References}

1. Eulgem T, Rushton P, Robatzek S, Somssich I. The WRKY superfamily of plant transcription factors. Trends Plant Sci. 2000;5:199-206.

2. Lagace $M$, Matton DP. Characterization of a WRKY transcription factor expressed in late torpedo-stage embryos of Solanum chacoense. Planta. 2004:219(1):185-9.

3. Johnson CS, Kolevski B, Smyth DR. Transparent TESTA GLABRA2, a trichome and seed coat development gene of Arabidopsis, encodes a WRKY transcription factor. Plant Cell. 2002;14:1359-75.

4. Miao Y, Laun T, Zimmermann P, Zentgraf U. Targets of the WRKY53 transcription factor and its role during leaf senescence in Arabidopsis. Plant Mol Biol. 2004;55:853-67.

5. Li W, Wang H, Yu D. Arabidopsis WRKY transcription factors WRKY12 and WRKY13 oppositely regulate flowering under short-day conditions. Mol Plant. 2016:9:1492-503.

6. Guan Y, Meng X, Khanna R, LaMontagne E, Liu Y, Zhang S. Phosphorylation of a WRKY transcription factor by MAPKs is required for pollen development and function in Arabidopsis. PLoS Genet. 2014;10(5):e1004384.

7. Rinerson Cl, Scully ED, Palmer NA, Donze-Reiner T, Rabara RC, Tripathi P, et al. The WRKY transcription factor family and senescence in switchgrass. BMC Genomics. 2015;16:1-17.

8. Suttipanta N, Pattanaik S, Kulshrestha M, Patra B, Singh SK, Yuan L. The transcription factor CrWRKY1 positively regulates the terpenoid indole alkaloid biosynthesis in Catharanthus roseus. Plant Physiol. 2011;157(4): 2081-93.

9. Zhang ZL. A rice WRKY gene encodes a transcriptional repressor of the gibberellin signaling pathway in aleurone cells. Plant Physiol. 2004;134(4): 1500-13.

10. Pandey SP, Roccaro M, Schon M, Logemann E, Somssich IE. Transcriptional reprogramming regulated by WRKY18 and WRKY40 facilitates powdery mildew infection of Arabidopsis. Plant J. 2010;64(6):912-23. 
11. Mukhtar MS, Deslandes L, Auriac MC, Marco Y, Somssich IE. The Arabidopsis transcription factor WRKY27 influences wilt disease symptom development caused by Ralstonia solanacearum. Plant J. 2008;56(6):935-47.

12. Chen C, Chen Z. Potentiation of developmentally regulated plant defense response by AtWRKY18, a pathogen-induced Arabidopsis transcription factor. Plant Physiol. 2002;129(2):706-16.

13. Li J, Brader G, Kariola T, Tapio Palva E. WRKY70 modulates the selection of signaling pathways in plant defense. Plant J. 2006;46:477-91.

14. Knoth C, Ringler J, Dangl JL, Eulgem T. Arabidopsis WRKY70 is required for full RPP4-mediated disease resistance and basal defense against Hyaloperonospora parasitica. Mol Plant-Microbe Interact. 2007;20:120-8.

15. Kim KC, Lai Z, Fan B, Chen Z. Arabidopsis WRKY38 and WRKY62 transcription factors interact with histone deacetylase 19 in basal defense. Plant Cell. 2008;20:2357-71

16. Peng $X$, Hu $Y$, Tang $X$, Zhou $P$, Deng $X$, Wang H, Guo Z. Constitutive expression of rice WRKY30 gene increases the endogenous jasmonic acid accumulation, PR gene expression and resistance to fungal pathogens in rice. Planta. 2012;236:1485-98.

17. Viana VE, Busanello C, da Maia LC, Pegoraro C, Costa de Oliveira A. Activation of rice WRKY transcription factors: an army of stress fighting soldiers? Curr Opin Plant Biol. 2018:45:268-75.

18. Cannon SB, Mitra A, Baumgarten A, Young ND, May G. The roles of segmental and tandem gene duplication in the evolution of large gene families in Arabidopsis thaliana. BMC Plant Biol. 2004;4(1):10.

19. Ross CA, Liu Y, Shen QJ. The WRKY gene family in rice (Oryza sativa). J Integr Plant Biol. 2007;49(6):827-42.

20. Wang L, Zhu W, Fang L, Sun X, Su L, Liang Z, Wang N, Londo JP, Li S, Xin H. Genome-wide identification of WRKY family genes and their response to cold stress in Vitis vinifera. BMC Plant Biol. 2014;14(1):103.

21. Huang X, Li K, Xu X, et al. Genome-wide analysis of WRKY transcription factors in white pear (Pyrus bretschneideri) reveals evolution and patterns under drought stress. BMC Genomics. 2015;16(1):1104.

22. Chen M, Tan Q, Sun M, Li D, Fu X, Chen X, Xiao W, Li L, Gao D. Genomewide identification of WRKY family genes in peach and analysis of WRKY expression during bud dormancy. Mol Gen Genomics. 2016;291:1319-32.

23. Liu MJ. Chinese jujube: botany and horticulture. In: Horticultural reviews, vol. 32; 2010. p. 229

24. Liu MJ, Zhao J, Cai QL, et al. The complex jujube genome provides insights into fruit tree biology. Nat Commun. 2014;5:5315.

25. Huang J, Zhang C, Zhao X, Fei Z, Wan K, Zhang Z, Pang X, Yin X, Bai Y, Sun X, Gao L, Li R, Zhang J, Li X. The jujube genome provides insights into genome evolution and the domestication of sweetness/acidity taste in fruit trees. PLoS Genet. 2016;12(12):e1006433.

26. Liu MJ, Zhao J, Wang JR, Liu ZG, Liu GC. Phylogenetic analysis of 25 plant species representing 19 angiosperm families and one gymnosperm family based on 390 orthologous genes. Plant Syst Evol. 2017;303(3):413-7.

27. Verde I, Abbott AG, Scalabrin S, et al. The high-quality draft genome of peach (Prunus persica) identifies unique patterns of genetic diversity, domestication and genome evolution. Nat Genet. 2013:45(5):487-94.

28. Liu Z, Zhang L, Xue C, Fang H, Zhao J, Liu M. Genome-wide identification and analysis of MAPK and MAPKK gene family in Chinese jujube (Ziziphus jujuba mill.). BMC Genomics. 2017;18:855.

29. Meng D, Li Y, Bai Y, et al. Genome-wide identification and characterization of WRKY transcriptional factor family in apple and analysis of their responses to waterlogging and drought stress. Plant Physiol Biochem. 2016;103:71-83.

30. Zhang $Y$, Wang $L$. The WRKY transcription factor superfamily: its origin in eukaryotes and expansion in plants. BMC Evol Biol. 2005;5(1):1.

31. Zheng X, Zhao Y, Shan D, et al. MdWRKY9 overexpression confers intensive dwarfing in the M26 rootstock of apple by directly inhibiting brassinosteroid synthetase MdDWF4 expression. The New phytologist. 2017;217(3):1086-98.

32. Journot-Catalino N, Somssich IE, Roby D, Kroj T. The transcription factors WRKY11 and WRKY17 act as negative regulators of basal resistance in Arabidopsis thaliana. Plant Cell. 2006;18:3289-302.

33. Ali MA, Wieczorek K, Kreil DP, Bohlmann H. The beet cyst nematode Heterodera schachtii modulates the expression of WRKY transcription factors in syncytia to favour its development in Arabidopsis roots. PLoS One. 2014;9:e102360.

34. Jiang CH, Huang ZY, Xie P, Gu C, Li K, Wang DC, Yu YY, Fan ZH, Wang CJ, Wang YP, et al. Transcription factors WRKY70 and WRKY11 served as regulators in rhizobacterium Bacillus cereus AR156-induced systemic resistance to Pseudomonas syringae pv. Tomato DC3000 in Arabidopsis. J Exp Bot. 2016;67:157-74.
35. Chen X, Liu J, Lin G, et al. Overexpression of AtWRKY28 and AtWRKY75 in Arabidopsis enhances resistance to oxalic acid and Sclerotinia sclerotiorum. Plant Cell Rep. 2013;32(10):1589-99.

36. Edwards R, Dixon DP. Plant glutathione transferases. Method Enzymol. 2005; 401:169-86

37. Ye X, Wang H, Chen P, Fu B, Zhang M, Li J, Zheng X, Tan B, Feng J. Combination of iTRAQ proteomics and RNA-seq transcriptomics reveals multiple levels of regulation in phytoplasma-infected Ziziphus jujuba mill. Hortic Res. 2017:4:17080.

38. Chujo T, Miyamoto K, Shimogawa T, Shimizu T, Otake Y, Yokotani N. OsWRKY28, a PAMP responsive transrepressor, negatively regulates innate immune responses in rice against rice blast fungus. Plant Mol Biol. 2013; 82(1):23-37.

39. Delteil A, Blein M, Faivre-Rampant O, Guellim A, Estevan J, Hirsch J. Building a mutant resource for the study of disease resistance in rice reveals the pivotal role of several genes involved in defence. Mol Plant Pathol. 2012; 13(1):72-82.

40. Xue C, Liu Z, Dai L, Bu J, Liu M, Zhao Z, Jiang Z, Gao W, Zhao J. Changing host photosynthetic, carbohydrate and energy metabolisms play important roles in phytoplasma infection. Phytopathology. 2018;108(9):1067-77.

41. Bailey TL, Boden M, Buske FA, Frith M, Grant CE, Clementi L, Ren J, Li WW, Noble WS. MEME SUITE: tools for motif discovery and searching. Nucleic Acids Res. 2009;37(Web Server):W202-8

42. Paterson AH, Bowers JE, Chapman BA. Ancient polyploidization predating divergence of the cereals, and its consequences for comparative genomics. Proc Natl Acad Sci. 2004;101(26):9903-8.

43. Guo A, Zhu Q, Chen X, Luo JGSDS. A gene structure display server. Yi Chuan. 2007;29:1023-6.

44. Lui S, Luo C, Zhu L, Sha R, Qu S, Cai B, Wang S. Identification and expression analysis of WRKY transcription factor genes in response to fungal pathogen and hormone treatments in apple (Malus domestica). Journal of Plant Biology. 2017;60(2):215-30.

45. Tamura K, Peterson D, Peterson N, Stecher G, Nei M, Kumar S. MEGA5: molecular evolutionary genetics analysis using maximum likelihood, evolutionary distance, and maximum parsimony methods. Mol Biol Evol. 2011;28(10):2731-9.

46. Saitou N, Nei M. The neighbor-joining method: a new method for reconstructing phylogenetic trees. Mol Biol Evol. 1987;4(4):406-25.

47. Bu J, Zhao J, Liu M. Expression stabilities of candidate reference genes for RT-qPCR in Chinese jujube (Ziziphus jujuba Mill.) under a variety of conditions. PLoS One. 2016;11(4):e0154212.

48. Livak KJ, Schmittgen TD. Analysis of relative gene expression data using realtime quantitative PCR and the $2^{-\triangle \Delta C T}$ method. Methods. 2001;25(4):402-8.

\section{Ready to submit your research? Choose BMC and benefit from:}

- fast, convenient online submission

- thorough peer review by experienced researchers in your field

- rapid publication on acceptance

- support for research data, including large and complex data types

- gold Open Access which fosters wider collaboration and increased citations

- maximum visibility for your research: over $100 \mathrm{M}$ website views per year

At $\mathrm{BMC}$, research is always in progress.

Learn more biomedcentral.com/submissions 